\title{
MORTALITY FACTORS IN GERIATRICS WITH NON-TRAUMATIC ABDOMINAL PAIN AT THE EMERGENCY DEPARTMENT
}

Turkish Journal of Geriatrics DOI:10.31086/tjgeri.2018137968 2018;21 (1):62-69

- Süha SERIN

- Bahadır ÇAĞLAR ${ }^{2}$

- Gökhan YILMAZ ${ }^{3}$

- Alper TORUN ${ }^{3}$

- İsmet PARLAK ${ }^{3}$

- Başak GÖL SERIN ${ }^{4}$

\section{Abstract}

Introduction: The purpose of this study was to determine the factors affecting mortality in geriatric patients presenting with non-traumatic abdominal pain at the emergency department.

Materials and Method: This cross-sectional, retrospective study included patients aged $\geq 65$ years who presented with non-traumatic abdominal pain at the emergency department. The demographic characteristics, laboratory test results, and in-hospital course of the patients were examined. The relationship between mortality and the data obtained was analyzed at a $95 \%$ confidence level and with a $p$ value of $<0.05$ considered statistically significant. The study was conducted following the approval of the ethics committee.

Results: A total of 1110 patients were included and comprised 619 (55.8\%) women; 719 $(64.8 \%)$ were admitted to the general surgery clinic and $211(19 \%)$ were operated on. Of those admitted to the general surgery clinic, $106(9.5 \%)$ cases resulted in mortality. The cut-off value of age for mortality was 73 years $[73.6 \%$ sensitivity, $40.4 \%$ specificity, and receiver operating characteristic - area under the curve (ROC-AUC) 0.581)]. A high lactate value (cut-off value 2.4) was associated with mortality (with $78.2 \%$ sensitivity, $68.8 \%$ specificity, and ROC-AUC $0.786)$. The most common predictors of mortality were perforation [odds ratio $(O R)=20.7$ ], ileus $(\mathrm{OR}=17.9)$, high lactate $(\mathrm{OR}=7.6)$, and hypocalcemia $(\mathrm{OR}=3.9)$.

Conclusion: In geriatric patients who presented with abdominal pain at the emergency department, mortality, which increased at the age of over 73 years, was determined mainly by electrolyte and lactate values.

Keywords: Geriatrics, Emergencies, Abdominal Pain, Mortality
CORRESPONDANCE

\section{Süha SERIN}

Urla City Hospital, Emergency Medicine Clinic İmir, Turkey

Phone: 02327354444

e-mail: suhaserin@gmail.com

Received: 04/01/2018

Accepted: 05/03/2018

1 Urla City Hospital, Emergency Medicine Clinic İzmir, Turkey

2 Elazığ Training and Research Hospital Emergency Medicine

Elazığ, Turkey

${ }^{3}$ Bozyaka Training and Research Hospital Emergency Medicine

İzmir, Turkey

${ }^{4}$ Tepecik Training and Research Hospital Infectious Diseases and Clinical Microbiology İzmir, Turkey

Presented in: ACEM 2017 (oral presentation) $9^{\text {th }}$ Asian Conference on Emergency Medicine \& $13^{\text {th }}$ Turkish Emergency Medicine Congress November 22-25, 2017, Regnum Carya Belek, Antalya / Turkey
ARAŞTIRMA

\section{ACIL SERVISTE TRAVMATIK OLMAYAN KARIN AĞRILI GERIATRIKK HASTALARDAKI MORTALITE FAKTÖRLERI}

\author{
$\ddot{O}_{z}$
}

Giriş: Bu çalışmanın amacı acil servise travmatik nedenli olmayan karın ağrısı ile başvuran geriatrik hastalarda mortaliteyi etkileyen faktörleri belirlemektir.

Gereç ve Yöntem: Bu retrospektif kesitsel çalışma, acil servise travmatik olmayan karın ağrısı ile başvuran 65 yaş ve üstü hastaları kapsamaktadır. Hastaların demografik özellikleri, laboratuvar test sonuçları ve hastane içi seyri incelendi. Mortalite ile elde edilen veriler arasındaki ilişki, \%95 güven düzeyinde ve $p<0.05$ ise istatistiksel olarak anlamlı kabul edildi. Çalışmamız etik kurul onayı ile gerçekleştirildi.

Bulgular: Toplam 1110 hasta dahil edildi; hastaların; 619'u (\% 55.8) kadındı, 719'u (\% 64.8) genel cerrahi kliniğine yatırıldı, 211'i (\% 19) ameliyat edildi. Genel cerrahi kliniğine yatanlardan 106 (\%9.5) olgu mortalite ile sonlandı. Mortalite yaş ilişkisinin cut-off değeri 73 yaş olarak bulundu [sensitivite \% 73.6, spesifisite \% 40.4 ve roc analizi - eğri altı alan (ROC-AUC) 0.581]. Laktat yüksekliği (cut-off değeri 2.4) mortalite ile ilişkili bulundu (\%78.2 sensitivite, $68.8 \%$ spesifisite ve ROC-AUC) 0.786). Mortaliteye etki eden en sık faktörler; perforasyon [odds oranı $(O R)=20.7$, ileus ( $O R$ 17.9), laktat yüksekliği $(O R=7.6)$ ve hipokalsemi $(O R=3.9)$ olarak bulundu.

Sonuç: Acil serviste travmatik nedenli olmayan karın ağrısı ile başvuran geriatrik hastalarda mortaliteye etki eden en sık faktörlerin; > 73 yaş olmak, elektrolit bozukluğu ve laktat yüksekliği olduğu saptandı.

Anahtar sözcükler: Yaşlılık, Aciller, Karın ağrısı, Mortalite 


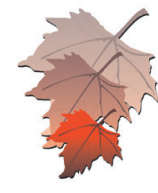

\section{INTRODUCTION}

It was predicted that by 2020, 1 in 6 people in the United States will be in the geriatric age group (1). According to the Turkish Statistical Institute (TSI) data, the population of Turkey in 2013 was 76.481.847, of which $7.7 \%$ (5,878,603 people) accounted for the geriatric population. This rate is estimated to be in $10.2 \%$ in 2023,20.8\% in 2050, and $27.7 \%$ (24.672.343 people) in 2075 (2).

Abdominal pain is one of the most common reasons for visit of geriatric patients at ED, accounting for approximately $2 \%$ of the total ED presentations (3). The age-related physiologic conditions make it difficult to evaluate geriatric patients $(4,5)$; as such, the ED has a critical role in the care of such patients because delays in the diagnosis and treatment can lead to increased morbidity and mortality $(4,5)$.

There have been studies suggesting that parameters, such as hypocalcemia and hyperlactatemia, reflected the current clinical picture and increased the in-hospital mortality in the geriatric population $(6,7)$. However, there have not been enough studies showing that these values affected mortality in patients complaining of abdominal pain. The aim of this study was to investigate the independent risk factors affecting mortality in geriatric patients presenting with nontraumatic abdominal pain at the ED.

\section{MATERIALS AND METHOD}

Approval for the study was granted by the local ethics committee. This retrospective crosssectional study included patients who presented at the Emergency Medicine Clinic of Izmir Bozyaka Training and Research Hospital between January 2013 and December 2015. During the study period, 570,428 patients were admitted to the ED of the hospital and $13 \%$ these patients were in the geriatric age group. Patient information was obtained by reviewing electronic files. Patients were included in the study consecutively.
For this study, files of patients aged 65 years and older who admitted to the emergency department and who had diagnosis codes that associated with abdominal pain for the ICD-10 list were analyzed (ICD codes between R10-19). Patients were not included in the study if they were younger than 65 years, presented at the ED due to trauma, had a trauma history in the past week, had no information on file or with missing data, left or were transferred from the hospital on their own request during the diagnosis or treatment phase, and when the acute abdominal pain was determined to be related to a non-abdominal pathology, such as acute myocardial infarction and pneumonia.

The laboratory parameters analyzed in the study were leukocyte count, renal function tests (RFT; i.e., urea and creatinine), liver function tests (LFTs; aspartate aminotransferase and alanine aminotransferase), amylase, total bilirubin, calcium, sodium, potassium, and chlorine. The levels of the electrolytes and the other parameters were taken into consideration. The reference values of the hospital laboratory were considered as the limit for all parameters.

\section{Statistical analysis}

The SPSS 22.0 (IBM Corporation, Armonk, New York, USA) and Medcalc 9 (Acacialan 22, B-8400 Ostend, Belgium) programs were used for data analysis. The normal distribution of the data was tested with the Shapiro-Wilk test and variance homogeneity was analyzed with the Levene test. In the comparison of two independent groups, the independent sample t-test was used with Bootstrap results and the Mann-Whitney $U$ test was used with the Monte Carlo simulation technique. In the comparison of categorical data, the Pearson Chi-Square and the Fisher's Exact tests were used together with the Monte Carlo simulation technique; the column ratios were compared with each other and expressed according to the p-values obtained after Bonferroni correction. 
The odds ratio (OR) was used to determine the most important risk factor in the comparison of categorical data. Backward logistic regression analysis was used to determine the cause-and-effect relationship of the categorical response variable with the explanatory variables in the diatom and multinominal categories. Quantitative data were expressed in the tables as mean \pm standard deviation, median \pm interquartile range (IQR), and median range (maximum-minimum) values. Categorical data were expressed as $n$ (number) and percentage (\%). The data were analyzed at 95\% confidence level and a $p$ value of $<0.05$ was considered statistically significant.

\section{RESULTS}

The study included a total of 1,110 patients that comprised 619 (55.8\%) women and 491 (44.2\%) men, with a mean age of $76.2 \pm 7.2$ years (range, 65-105 years). Clinical diagnoses were made in 783 patients (70.5\%). Non-specific abdominal pain was seen in 327 patients who were discharged following ED follow-up. The distribution of the clinical diagnoses are summarized in Table 1.

Table 1. Clinical diagnosis distributions of the patients.

\begin{tabular}{lcr}
\hline Diagnosable & $\mathbf{n}$ & \% \\
\hline Bile pathologies & 177 & 22.6 \\
Pancreatic pathologies & 162 & 20.7 \\
Ileus and subileus & 155 & 19.8 \\
Perforation & 54 & 6.9 \\
Hernia & 49 & 6.2 \\
Appendix pathologies & 44 & 5.7 \\
Intra-abdominal abscess & 9 & 1.1 \\
Mesentery ischemia & 22 & 2.8 \\
Diverticulitis & 16 & 2.0 \\
Other diagnoses & 95 & 12.1 \\
\hline
\end{tabular}

Other Diagnoses: Gastrointestinal system (GIS) malignancy, intestnal fistula, intra-abdominal fluid, spleen infarction, GIS bleeding, hematoma, ileal torsion, hydatid cyst, inflammatory bowel disease (IBD), lymphoma, ovarian mass, rectovaginal fistula, urinary stone and volvulus-

In the study population, laboratory tests showed leukocytosis in 53.6\%, high RFT in 59.1\%, high LFT in $34.5 \%$, hyperamylasemia in $35.4 \%$, hyperbilirubinemia in $22.8 \%$, hypocalcemia in $14.6 \%$, hypercalcemia in $2.6 \%$, hyponatremia in $29.8 \%$, hypernatremia in $3.2 \%$, hypokalemia in $12.3 \%$, hyperkalemia in $3.5 \%$, hypochloremia in
$25 \%$, and hyperchloremia in 5.8\%. Compared with the patient group who was not hospitalized, the hospitalized patient group had significantly higher rates of high RFT $(p=0.001)$, high LFT $(p<0.001)$, hyperamylasemia $(p<0.001)$, hyponatremia $(p=0.003)$, hypokalemia $(p=0.034)$, and hypochloremia $(p=0.019)$. 
Of the 1,110 patients included in the study, 719 (64.8\%) were admitted to the general surgery clinic, of which 211 (19\%) were operated on. Of the patients for whom hospitalization was recommended, 83 (7.5\%) refused to be hospitalized. The clinical course of 106 (9.5\%) patients resulted in mortality. The mean age was 78.2 years in the patient group that resulted in mortality and 76.0 years in the surviving patient group, with a significant difference between the groups $(t=2.91, p<0.05)$.

Upon analysis of the 106 patients who died using $95 \% \mathrm{Cl}$, mortality risk was noted to increase by 1.3 times in patients aged $\geq 80$ years $(O R=1.3$,
$95 \% \mathrm{Cl}=0.84-1.91)$ and by 1.9 times in patients aged $\geq 73$ years $(\mathrm{OR}=1.9,95 \% \mathrm{Cl}=1.2-2.9)$. Therefore, the optimal cut-off value for agerelated mortality was determined to be 73 years. At this cut-off value of $\geq 73$ years $(73.6 \%$ sensitivity, $40.4 \%$ specificity, AUC $0.581 \pm 0.027, p=0.004)$, mortality rate was observed to be $3.8(95 \% \mathrm{Cl}$, 1.9-7.4) times higher in patients who underwent operation, but it was not significantly affected in patients who did not undergo surgery $(p<0.001)$. A lactate value of $>2.4$ (78.2\% sensitivity, $68.8 \%$ specificity, AUC $0.786 \pm 0.035$ ) on presentation was determined to increase the mortality risk by 7.9 times $(\mathrm{OR}=7.9,95 \% \mathrm{Cl}=3.97-15.76)$ (Graphic 1).
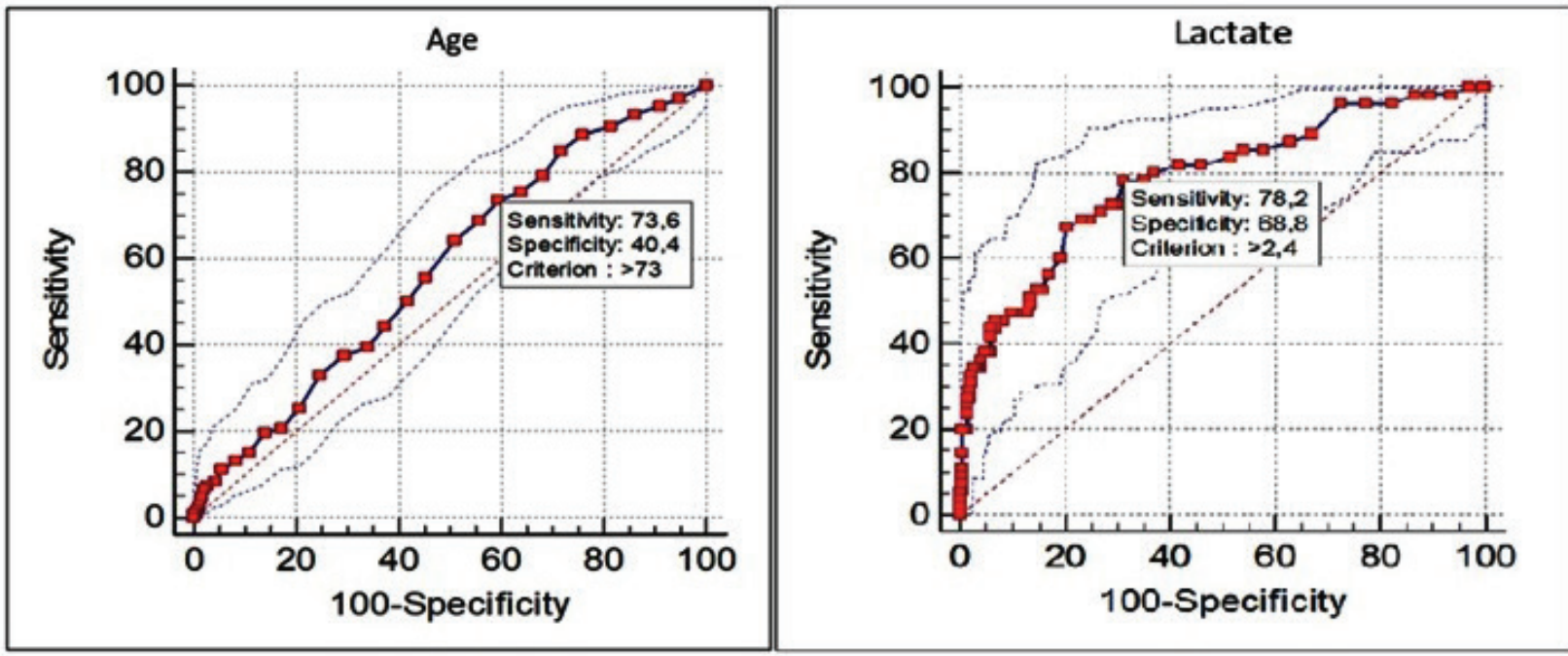

Graphic 1 . The mortality risk for the cut-off value for age is $>73$ years \& the cut-off value for lactate is $>2.4$

Among the diagnoses made, only the diagnosis of perforation was shown to increase mortality rate (OR=10, 95\% Cl, p<0.001) (Table2).

Considering the effects of all the non-diagnostic parameters analyzed, mortality was significantly increased in patients who were operated on
$(\mathrm{OR}=9.3,95 \% \mathrm{Cl}=6.1-14.3)$ and in those with high RFT level (OR=2.1, 95\% Cl=1.3-3.2); hypocalcemia $(\mathrm{OR}=2.9,95 \% \mathrm{Cl}=1.8-4.6)$; hyponatremia $(\mathrm{OR}=1.6$, 95\% Cl=1.03-2.35); hypokalemia (OR=2.9, 95\% $\mathrm{Cl}=1.8-4.7)$; and hypochloremia (OR=2.14, 95\% $\mathrm{Cl}=1.4-3.2$ ) (Table 3). 
Table 2. The predictivite effect of the diagnoses on mortality.

\begin{tabular}{|c|c|c|c|c|}
\hline \multirow{3}{*}{ Diagnosis } & \multicolumn{4}{|c|}{ Survival } \\
\hline & Alive & Exitus & & \\
\hline & $\begin{array}{r}\text { Number of patients } \\
\mathrm{n}(\%)\end{array}$ & $\begin{array}{r}\text { Number of patients } \\
n(\%)\end{array}$ & $\begin{array}{r}\text { Odds Ratio } \\
(95 \% \mathrm{Cl})\end{array}$ & $\mathrm{p}$ value \\
\hline $\begin{array}{l}\text { Appendix } \\
\text { pathologies }\end{array}$ & $43(5.8)$ & $1(1.0)$ & $0.15(0.02-1.15)$ & $<0.001$ \\
\hline Other & $122(16.4)$ & $20(19.0)$ & $1.25(0.7-2)$ & \\
\hline Hernia & $46(6.2)$ & $3(2.9)$ & $0.45(0.13-1.47)$ & \\
\hline Ileus and subileus & $131(17.6)$ & $24(22.9)$ & $1.4(0.8-2.5)$ & \\
\hline $\begin{array}{l}\text { Pancreas } \\
\text { pathologies }\end{array}$ & $157(21.1)$ & $5(4.8)$ & $0.18(0.07-0.46)$ & \\
\hline Perforation & $26(3.5)$ & $28(26.7)$ & $10(5.6-17.8)$ & \\
\hline Bile pathologies & $157(21.1)$ & $20(19.0)$ & $0.8(0.5-1.5)$ & \\
\hline $\begin{array}{l}\text { Examination }+ \\
\text { Follow up }\end{array}$ & $62(8.3)$ & $4(3.8)$ & $0.4(0.15-1.22)$ & \\
\hline
\end{tabular}

Pearson Chi-Square Test (Monte Carlo) - Fisher Exact Test (Exact)

Table 3. Predictivite effect of clinic and laboratory parameters on mortality.

\begin{tabular}{|c|c|c|c|c|c|c|}
\hline & & & \multicolumn{4}{|l|}{ Survival } \\
\hline & & & \multirow{2}{*}{$\begin{array}{l}\text { Alive } \\
\text { Number of } \\
\text { patients n (\%) }\end{array}$} & \multicolumn{3}{|l|}{ Exitus } \\
\hline & & & & $\begin{array}{l}\text { Number of } \\
\text { patients } \mathrm{n}(\%)\end{array}$ & Odds Ratio $(95 \% \mathrm{Cl})$ & $p$ value \\
\hline Operation & $\begin{array}{l}\text { Absent } \\
\text { Present }\end{array}$ & I & $\begin{array}{l}858(85.5) / \\
146(14.5)\end{array}$ & $\begin{array}{l}41(38.7) / \\
65(61.3)\end{array}$ & $9.3(6.1-14.3)$ & $<0.001$ \\
\hline RFT level & $\begin{array}{l}\text { Absent } \\
\text { Present }\end{array}$ & / & $\begin{array}{l}426(42.4) / \\
578(57.6)\end{array}$ & $\begin{array}{l}28(26.4) / \\
78(73.6)\end{array}$ & $2.1(1.3-3.2)$ & $<0.001$ \\
\hline LFT level & $\begin{array}{l}\text { Absent } \\
\text { Present }\end{array}$ & / & $\begin{array}{l}661(65.8) / \\
343(34.2)\end{array}$ & $\begin{array}{l}66(62.3) / \\
40(37.7)\end{array}$ & $1.2(0 . \quad-1.767)$ & 0.454 \\
\hline Amylase level & $\begin{array}{l}\text { Absent } \\
\text { Present }\end{array}$ & l & $\begin{array}{l}651(64.8) / \\
353(35.2)\end{array}$ & $\begin{array}{l}66(62.3) / \\
40(37.7)\end{array}$ & $1.1(0.7-1.7)$ & 0.595 \\
\hline Hypocalcemia & $\begin{array}{l}\text { Absent } \\
\text { Present }\end{array}$ & / & $\begin{array}{l}874(87.1) / \\
130(12.9)\end{array}$ & $\begin{array}{l}74(69.8) / \\
32(30.2)\end{array}$ & $2.9(1.8-4.6)$ & $<0.001$ \\
\hline Hypercalcemia & $\begin{array}{l}\text { Absent } \\
\text { Present }\end{array}$ & / & $\begin{array}{l}978(97.4) / \\
26(2.6)\end{array}$ & $\begin{array}{l}103(97.2) / \\
3(2.8)\end{array}$ & $1.1(0.33-3.68)$ & 0.752 \\
\hline Hyponatremia & $\begin{array}{l}\text { Absent } \\
\text { Present }\end{array}$ & / & $\begin{array}{l}714(71.1) / \\
290(28.9)\end{array}$ & $\begin{array}{l}65(61.3) / \\
41(38.7)\end{array}$ & $1.6(1.03-2.35)$ & 0.044 \\
\hline Hypernatremia & $\begin{array}{l}\text { Absent } \\
\text { Present }\end{array}$ & / & $\begin{array}{l}973(96.9) / \\
31(3.1)\end{array}$ & $\begin{array}{l}101(95.3) / \\
5(4.7)\end{array}$ & $1.5(0.59-4.1)$ & 0.38 \\
\hline Hypopotassemia & $\begin{array}{l}\text { Absent } \\
\text { Present }\end{array}$ & / & $\begin{array}{l}895(89.1) / \\
109(10.9)\end{array}$ & $\begin{array}{l}78(73.6) / \\
28(26.4)\end{array}$ & $2.9(1.8-4.7)$ & $<0.001$ \\
\hline Hyperpotassemia & $\begin{array}{l}\text { Absent } \\
\text { Present }\end{array}$ & / & $\begin{array}{l}969(96.5) / \\
35(3.5)\end{array}$ & $\begin{array}{l}102(96.2) / \\
4(3.8)\end{array}$ & $1.1(0.38-3.1)$ & 0.783 \\
\hline Hypochloremia & $\begin{array}{l}\text { Absent } \\
\text { Present }\end{array}$ & / & $\begin{array}{l}768(76.5) / \\
236(23.5)\end{array}$ & $\begin{array}{l}64(60.4) / \\
42(39.6)\end{array}$ & $2.14(1.4-3.2)$ & $<0.001$ \\
\hline Hyperchloremia & $\begin{array}{l}\text { Absent } \\
\text { Present }\end{array}$ & / & $\begin{array}{l}950(94.6) / \\
54(5.4)\end{array}$ & $\begin{array}{l}96(90.6) / \\
10(9.4) \\
\end{array}$ & $1.8(0.9-3.7)$ & 0.12 \\
\hline
\end{tabular}

Pearson Chi-Square Test (Monte Carlo) - Fisher Exact Test (Exact) C.I: Confidence Interval 
In this study, all parameters were analyzed using multiple logistic regression. After exclusion of the confounding effects, the following five basic conditions were detected to increase the mortality risk; these included surgery $(\mathrm{OR} 2.53,95 \% \mathrm{Cl} 1.03$ 6.22); the diagnoses of perforation (OR $20.7,95 \% \mathrm{Cl}$
1.72-249.51) and ileus-subileus (OR 17.96, 95\% Cl 1.91-169.09); and laboratory results on presentation at the ED showing hypocalcemia (OR3.92, 95\% Cl 1.49-10.33) and lactate $>2.4$ (OR7.67,95\% Cl 3.0419.32) (Table 4).

Table 4. Factors affecting mortality when confounding effects are excluded.

\begin{tabular}{lrrr}
\hline Independent Variables & B \pm sd & p value & $\begin{array}{r}\text { Odds Ratio } \\
(\mathbf{9 5 \%} \mathrm{Cl})\end{array}$ \\
\hline Undergoing surgery & $-0.292 \pm 0.459$ & $\mathbf{0 . 0 4 3}$ & $2.53(1.03-6.22)$ \\
Lactate $(>2.4)$ & $-2.037 \pm 0.472$ & $<0.001$ & $7.67(3.04-19.32)$ \\
Ileus and Subileus & $2.888 \pm 1.144$ & $\mathbf{0 . 0 1 2}$ & $17.96(1.91-169.09)$ \\
Perforation & $3.030 \pm 1.270$ & $\mathbf{0 . 0 1 7}$ & $20.70(1.72-249.51)$ \\
Hypocalcemia & $-1.367 \pm .0494$ & $\mathbf{0 . 0 0 6}$ & $3.92(1.49-10.33)$ \\
\hline
\end{tabular}

Dependent Variable:Mortality Predicted Survivals=95\% Predicted Ex=95\% Predicted:\%88.1 P Model<0.001

MultipleLogisticRegression (Method=BackwardStepwise (Wald))

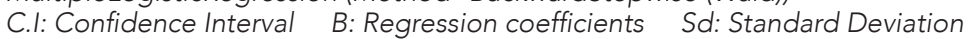

\section{DISCUSSION}

Abdominal pain is one of the most difficult symptoms to be investigated and diagnosed in the geriatric age group (8). In previous studies, rates of hospitalization, duration of hospitalization, need for surgery, and mortality rates have been found to be relatively high in the geriatric age group with abdominal pain (9-12). Approximately 20\% of patients in this age group undergo an invasive intervention or surgery (13). In addition, these patients may present with atypical or delayed abdominal pain or extra-abdominal pathologies $(14,15)$. For example, one study showed that the classic symptoms of perforated appendicitis were limited to only $17 \%$ in the geriatric age group (16). Inadequate diagnosis or misdiagnosis increases the morbidity and mortality rates significantly (17). These patients are not only exposed to more aggressive interventions and investigations, but they also tend to be cured less than younger patients. Cumulatively, patients in this age group create a higher economic burden.
The most common pathology of the patients in this study was biliary (22.6\%).In a study on 131 geriatric patients, the most common diagnosis was biliary disease in men and non-specific abdominal pain in women. In a study conducted by Catherine et al. on geriatric patients who presented with abdominal pain at the ED, infection (19.2\%) was the most common diagnosis, whereas biliary pathology accounted for only $5.9 \%$ of the diagnoses (18). In the present study, $19 \%$ of the patients were operated on.

In the study by Catherine et al, the mortality rate was found to be $5.3 \%$ (18). There were studies showing mortality rates as high as $40 \%$ in patients over 80 years of age who presented with abdominal pain (13). In the present study, the mortality rate was $9.5 \%$.

In this study, mortality rate was measured based on in-hospital data only; this fact suggested that the actual mortality rate can be higher. In the study by Gardner et al on 131 geriatric patients, mortality 
within three months following admission to the ED occurred in $19 \%$ of men and in $1 \%$ of women. A study performed on 132 patients over 80 years of age and who presented with acute abdominal pain showed an in-hospital mortality rate of $17 \%$. Of these patients, 35 needed operations, and the mortality rate was $34 \%$ in those who underwent surgery (12). Similarly, in the present study, operation was one of the independent variables that affected mortality. This high risk of perioperative mortality was probably due to the increased number of comorbid diseases in the geriatric population and the varying age-related physiologic characteristics that make postoperative care difficult $(19,20)$.

Studies have shown that lactate level, which is one of the important indicators of hypoperfusion, predicted the prognosis in some adult age groups. The lactate level is also known to be associated with mortality in the geriatric population; in fact, various studies showed that increased lactate levels increased the mortality rate by 2-20 times in the geriatric group $(7,21,22)$. There were studies showing that venous lactate level, compared with conventional vital sign monitoring, was a stronger predictor of mortality in a geriatric group that presented with trauma (22). In addition, several studies showed the value of lactate levels in predicting mortality in geriatric patients in septic shock, those who underwent trauma laparotomy, and those who needed intensive care $(7,23)$. In the present study, a lactate level of $>2.4$ was shown to predict mortality. However, to the best of our knowledge, the number of published studies that analyzed the relationship between lactate and mortality in geriatric patients presenting with abdominal pain is limited. Further studies applied in this context will ensure clarification of the subject.

Several studies have shown that hypocalcemia was an important prognostic factor in acute pancreatitis. In addition, recent studies have shown that patients with comorbidities associated with hypocalcemia had increased mortality rates upon presentation at the ED and that correction of hypocalcemia in critical care patients reduced the mortality risk $(24,25)$. However, there have not been enough studies showing the relationship between hypocalcemia and mortality in a geriatric population presenting with abdominal pain. In this study, hypocalcemia was one of the independent variables that predicted mortality.

Although factors, such as high RFT, hyponatremia, hypokalemia, and hypochloremia increased mortality in the univariate analysis, these were not determined to independently increase mortality in the multivariate analysis. There is a limited number of published studies that investigated the association of electrolyte disturbances with mortality in geriatric patients presenting with abdominal pain.

On investigation of geriatric patients presenting with abdominal pain at the ED, the factors affecting mortality were found to be laboratory test results of elevated lactate levels and hypocalcemia; diagnoses of perforation and ileus-subileus; and surgical intervention. Mortality significantly increased in patients aged $\geq 73$ years. In the management of geriatric patients at the ED, attention must be paid to these factors that can increase mortality.

\section{Limitations of the study}

In the present study, only in-hospital mortality was evaluated, and the possible morbidity and post-discharge mortality could not be analyzed. Future studies on out-of-hospital mortality rate in the geriatric age group would be of particular contribution.

\section{ACKNOWLEDGMENTS}

We clearly declare that there are no conflicts of interest. SS, BC, and AT collected the data. SS, GY, BGS and IP analyzed the data. 


\section{REFERENCES}

1. US Bureau of the census. Statistical abstract of the United States, 2012; ed:131, Washington DC, 2011. [Internet] Available from: https://www2. census.gov/library/publications/2011/compendia/ statab/131ed/2012-statab.pdf. Accessed:01.11.2017.

2. Turkish Statistical Institute. Statistics by Theme; Population Projections; Statistical Tables and Dynamic Search; Statistical Tables; Population Projections and Estimations; Population of Selected Age Groups by Scenarios. (In Turkish) [Internet] Available from: http://www.turkstat.gov.tr/PreTablo. do?alt_id=1027. Accessed:01.11.2017.

3. Fagbohun CF, Toy EC, Baker B. The evaluation of acute abdominal pain in the elderly patient. Prim Care Update Ob/Gyns 1999;6(6):181-5.

4. Mion LC, Palmer RM, Anetzberger GJ, et al. Establishing a case finding and referral system for atrisk older individuals in the emergency department setting: the SIGNET model. J Am Geriatr Soc 2001;49:1379-86. (PMID:11890500).

5. Aminzadeh F, Dalziel WB. Older adults in the emergency department: a systematic review of patterns of use, adverse outcomes, and effectiveness of interventions. Ann Emerg Med 2002;39:238-47. (PMID:11867975).

6. Chang WT, Radin B, McCurdy MT. Calcium, magnesium, and phosphate abnormalities in the emergency department. Emerg Med Clin North Am 2014;32(2):349-66. (PMID:24766937).

7. Joseph B, Zangbar B, Pandit V, et al. Mortality after trauma laparotomy in geriatric patients. J Surg Res 2014;190(2):662-6. (PMID:24582068).

8. McNamara RM, Rousseau E, Sanders AB. Geriatric emergency medicine: a survey of practice in emergency physicians. Ann Emerg Med 1992;21:796801. (PMID:1610035).

9. Bugliosi TF, Meloy TD, Vukov LF. Acute abdominal pain in the elderly. Ann Emerg Med 1990;19:1383-6. (PMID:2240749).

10. Kizer KW, Vassar MJ. Emergency department diagnosis of abdominal disorders in the elderly. Am J Emerg Med 1998;16:357-62. (PMID:9672450).

11. Lewis LM, Banet GA, Blanda M, et al. Etiology and clinical course of abdominal pain in senior patients: a prospective, multicenter study. J Gerontol A Biol Sci Med Sci 2005;60:1071-6. (PMID:16127115).

12. vanGeloven AA, Biesheuvel TH, Luitse JS, et al. Hospital admissions of patients aged over 80 with acute abdominal complaints. Eur J Surg 2000;166:866-71. (PMID:11097153).

13. Magidson PD, Martinez JP. Abdominal pain in the geriatric patient. Emerg Med Clin North Am 2016;34(3):559-74. (PMID:27475015).

14. Ragsdale L, Southerland L. Acute abdominal pain in the older adult. Emerg Med Clin North Am 2011;29(2):429-48. (PMID:21515186).

15. Gardner RL, Almeida R, Maselli JH et al. Does gender influence emergency department management and outcomes in geriatric abdominal pain? J Emerg Med 2010;39(3):275-81. (PMID:18993017).

16. Paranjape C, Dalia S, Pan J, et al. Appendicitis in the elderly: a change in the laparoscopic era. Surg Endosc 2007;21(5):777-81. (PMID:17285390).

17. Fenyo G. Acute abdominal disease in the elderly: experience from two series in Stockholm. Am J Surg 1982;143:751-4. (PMID:7091511).

18. Marco CA, Schoenfeld CN, Keyl PM, et al. Abdominal pain in geriatric emergency patients: variables associate with adverse outcomes. Acad Emerg Med 1998; 5:1163-8. (PMID:9864129).

19. Aubrun F, Gazon M, Schoeffler M, et al. Evaluation of perioperative risk in elderly patients. Minerva Anestesiol 2012;78(5):605-18. (PMID:22269928).

20. Desserud KF, Veen T, Søreide K. Emergency general surgery in the geriatric patient. Br J Surg 2016;103(2):e52-61. (PMID:26620724).

21. Julián-Jiménez A, González-Del-Castillo J, MartínezOrtiz-de-Zárate $M$, et al. Short-term prognostic factors in the elderly patients seen in emergency departments due to infections. Enferm Infecc Microbiol Clin 2017;35(4):214-219. (PMID:26702902).

22. Salottolo KM, Mains CW, Offner PJ, et al. A retrospective analysis of geriatric trauma patients: venous lactate is a better predictor of mortality than traditional vital signs. Scand J Trauma Resusc Emerg Med 2013;21:7. (PMID:23410202).

23. Mock K, Keeley J, Moazzez A, et al. Predictors of mortality in trauma patients aged 80 years or older. Am Surg 2016;82(10):926-29. (PMID:27779975).

24. Sauter TC, Lindner G, Ahmad SS, et al. Calcium disorders in the emergency department: independent risk factors for mortality. PLoS One 2015;10(7): e0132788. (PMID:26172117).

25. Miura S, Yoshihisa A, Takiguchi M, et al. Association of hypocalcemia with mortality in hospitalized patients with heart failure and chronic kidney disease. J Card Fail 2015;21(8):621-7. (PMID:25982827). 